\title{
Sedimentology of the early Neoproterozoic Morar Group in northern Scotland: implications for basin models and tectonic setting
}

\author{
H. C. Bonsor ${ }^{1 *}$, R. A. Strachan ${ }^{2}$, A. R. Prave $^{3}$ and M. Krabbendam ${ }^{1}$
}

${ }^{1}$ British Geological Survey, Murchison House, West Mains Road, Edinburgh, EH9 3LA, UK

* corresponding author: (H. C. Bonsor) email: helnso@bgs.ac.uk

${ }^{2}$ School of Earth and Environmental Sciences, University of Portsmouth, Portsmouth, PO1 3QL, UK

${ }^{3}$ Department of Earth Sciences, University of Andrews, St Andrews, KY16 9AL, UK

\begin{abstract}
The metasedimentary rocks of the Morar Group in northern Scotland form part of the early Neoproterozoic Moine Supergroup. The upper part of the Group is c. 2-3 km thick and contains two large km-scale facies successions: a coarsening-upwards marine-to-fluvial regression overlain by a fining-upwards fluvial-to-marine transgression. Fluvial facies make up less than a third of the total thickness; shallow-marine lithofacies comprise the remainder. Combining these new findings with previously published data indicates that the Morar Group represents, overall, a transgressive stratigraphic succession $c$. 6-9km thick, in which there is both an upward and eastward predominance of shallow-marine deposits, and a concomitant loss of fluvial facies. Smaller-scale (100s of m thick) transgressive-regressive cycles are superimposed on this transgressive trend. Collectively, the characteristics of the succession are consistent with deposition in a foreland basin located adjacent to the Grenville orogen, and possibly linked to the peri-Rodinian ocean. Subsidence and progressive deepening of the Morar basin may have, at least in part, been driven by loading of Grenville-orogenyemplaced thrust sheets, and aided by sediment loading. However, the relative contributions of thrust loading versus plate boundary effects and/or eustatic sea-level rise on basin evolution remain speculative.
\end{abstract}

Keywords: Neoproterozoic; sedimentology; Moine Supergroup; Morar Group; shallow marine; braidplain; foreland basin 
Analysis of the sedimentology and depositional environments of metasedimentary successions within the high-grade cores of mountain belts is often problematic as much detail is commonly obscured by the effects of polyphase deformation and metamorphic recrystallisation. These problems are compounded within Precambrian successions by a lack of palaeontological control. Nonetheless, in some orogens it has proved possible to reconstruct the main depositional environments in areas where the structural setting is relatively straightforward and exposure is of good quality. In this context, much research has been carried out on the sedimentology and basin setting of the deformed and polymetamorphic Moine Supergroup of northern Scotland (Strachan 1986; Glendinning 1988; Soper et al. 1998; Bonsor \& Prave 2008; Krabbendam et al. 2008; Bonsor et al. 2010). This is one of a number of thick early Neoproterozoic siliciclastic successions that were deposited in the North Atlantic region during and after the amalgamation of Laurentia, Baltica and Amazonia that resulted in the Grenville orogeny and the formation of the Rodinia Supercontinent (Fig 1; Hoffman 1991; Li et al. 2008). Other broadly coeval successions in the region include the Torridon Group of Scotland (Stewart 2002), the Krummedal Succession of East Greenland (Sønderholm et al. 2008) and the Krossfjorden Group and the Murchisonfjorden Supergroup of Svalbard (Pettersson et al. 2009) amongst others. All these sequences contain detrital zircon patterns suggesting an eastern Laurentian provenance, with abundant detritus derived from the Grenville orogen (Cawood et al. 2007; Pettersson et al. 2009). All successions, with the exception of the Torridon Group, have been subsequently strongly deformed and metamorphosed during Neoproterozoic (e.g. Knoydartian) and/or early Palaeozoic (Caledonian) orogenic events.

The basinal setting of the Moine Supergroup has been the focus of debate. It was interpreted as a shallow-marine rift basin (Strachan 1986; Glendinning 1988; Soper et al. 1998), perhaps representing a 'failed rift' in the core of Rodinia (Fig. 1a; Dalziel \& Soper 2001). Partly, on the basis of detrital zircon data, Cawood et al. (2004) suggested an intracratonic setting. Krabbendam et al. (2008), while working in the lowermost Morar Group, documented fluvial braidplain deposits similar to the Torridon Group farther west, and suggested molasse-type deposition in a foreland basin to the Grenville Orogen. Subsequent research in the stratigraphically middle part of the Morar Group (Bonsor et al. 2010), showed a gradual change from fluvial to tidally influenced shallow-marine deposits. This change was interpreted as recording the transition from dominantly non-marine sedimentation, linked to the erosion of the Grenville orogenic belt, to marine-influenced sedimentation related to the 
peri-Rodinian ocean (Fig. 1b). In this paper, we extend our analysis of the sedimentology and depositional environments of the Morar Group to its upper part. This provides a complete transect through this major siliciclastic succession in northern Scotland and places further constraints on basin and tectonic settings for this and correlative successions that accumulated in the present-day circum-North Atlantic region during, and following, the assembly of the Rodinia supercontinent.

\section{Geological Setting}

The Morar Group forms the lowest part of the Moine Supergroup and mainly comprises thick sequences of meta-sandstone (psammite) with subordinate meta-siltstone (semi-pelite) and meta-mudstone (pelite) (Strachan et al. 2010). The outcrop of the Morar Group is bounded to the west by the Moine Thrust, which forms the margin of the Caledonian orogen in Scotland, and to the east by the Sgurr Beag Thrust (Fig. 2a). The generally pelitic Glenfinnan Group and psammitic Loch Eil Group occur in the hanging wall of the latter fault and are considered to stratigraphically overlie the Morar Group (Holdsworth et al. 1987; 1994; Soper et al 1998). Inliers of Archaean ('Lewisianoid') gneiss, commonly highly deformed, are thought to represent the basement on which the Moine rocks were deposited (e.g. Ramsay et al. 1957; Holdsworth 1989; Friend et al. 2003). The Morar Group contains detrital zircons that yield $\mathrm{U}-\mathrm{Pb}$ ages of between 1.7 and $1.0 \mathrm{Ga}$ (Friend et al. 2008; Kirkland et al. 2008) and these have been interpreted to be derived from a variety of units within eastern Laurentia (Friend et al. 2003; Cawood et al. 2007; Kirkland et al. 2008), with significant detrital input from the Grenville orogen (Krabbendam et al. 2008). The youngest reliable concordant zircon grains reported from different samples are $1032 \pm 24 \mathrm{Ma}$ (Friend et al. 2003); $1022 \pm 24 \mathrm{Ma}$ (Kirkland et al. 2008) and $985 \pm 6$ Ma (Peters, 2001). The structural and metamorphic complexity of the Moine rocks results from polyphase deformation during the Knoydartian (c. 820-725 Ma) and both phases of the Caledonian - the Grampian (470-460 Ma) and Scandian (435-425 Ma) orogenic events (Strachan et al. 2002, 2010; Cutts et al. 2010).

Although the Morar Group is deformed by kilometre-scale folds and shear zones and metamorphosed to amphibolite facies, in large areas the strain is low enough to allow reconstruction of the original stratigraphy and permits detailed sedimentological analysis. One such area is the type locality of the Morar Group on the eponymous peninsula (Fig. 2a), where detailed sedimentological analyses have been undertaken previously (Glendinning 
1988; Bonsor \& Prave 2008). Our work reports on another region, some $100 \mathrm{~km}$ northeast of the type locality (Fig. 2a), wherein previous workers (Sutton \& Watson 1954; working in the Fannichs area, see Fig. 2a) constructed a local stratigraphical framework that was then used throughout northern Scotland. Krabbendam et al. (2011) have revised this stratigraphy and defined five units in the Morar Group, from base to top, the Altnaharra, Glascarnoch, Vaich, Crom and Debiedale formations, over a stratigraphic thickness of 6-9 km. The Altnaharra Formation (3-5 km thick) has been interpreted as a fluvial braidplain deposit (Krabbendam et al. 2008, 2011; Bonsor et al. 2010) deposited nonconformably on Lewisianoid basement slivers that have been caught up along the Moine and Achness thrust faults (Krabbendam et al. 2011; Figs. 2a and 3). It can be correlated across the Achness Thrust and traced for some $50 \mathrm{~km}$ southwest-ward to the Ullapool area where the Morar Group succession is unbroken by any major thrust faults. There, the stratigraphy youngs eastward until being either intruded by the Carn Chuinneag Granite (Wilson \& Shepherd 1979) or truncated by the Sgurr Beag Thrust (Fig. 3). The Altnaharra Formation above the Achness Thrust is highly deformed but strain decreases in the overlying Glascarnoch Formation and enough sedimentological detail is preserved to permit recognition of a distal fluvial braidplain to shallow-marine transgressive succession (Bonsor et al. 2010; Fig. 3). The Altnaharra and Glascarnoch formations exhibit complementary thinning/thickening trends such that the former thins eastwards whilst the latter thickens, and each may be, in part, lateral equivalents of the other (Bonsor et al. 2010; Krabbendam et al. 2011).

In this paper, we examine the stratigraphically highest levels of the Morar Group exposed in Glen Calvie (Figs. 2c and 3). The transition from the upper Glascarnoch Formation into the overlying succession of the Vaich Pelite through to the Crom Psammite and Diebidale Pelite formations can be observed in the study area (Fig. 2c and 3). The main focus is the Crom Psammite Formation, as the pelitic formations are generally too deformed to allow for refined sedimentological analysis. This area forms a convenient linkage to compare depositional trends between the Sutherland outcrops in northernmost Scotland and the Fannichs area to the southwest.

\section{Sedimentology of the upper Morar Group: Crom Psammite Formation}

Facies type and architecture 
The Crom Psammite Formation is between 2 and $3 \mathrm{~km}$ thick and comprises micaceous to quartzitic psammite interbedded with varying amount of pelite. The formation is bounded below and above by the Vaich and Debidale Pelite formations, respectively (Fig. 2c), each between $0.3-0.7 \mathrm{~km}$ thick (although these thicknesses are likely to be maximum thicknesses as a result of thickening by folding). Although the rocks have undergone amphibolite-facies metamorphism, original sedimentary structures are well preserved in much of the area, particularly west of Glen Calvie (Figs. 2b and c).

Four main lithofacies are identified in the Crom Psammite Formation on the basis of their sedimentology: LFC1, LFC2, LFC3, and LFC4. Gradual and systematic transitions between these lithofacies define a coarsening-upward succession in the lower part of the stratigraphy and then a changeover to a fining-upward succession throughout the remainder of the succession. These successions are recognised by an upward increase and then decrease in the proportion of psammite, matched by a complementary trend in pelite. It should be noted that the recognition and definition of a lithofacies was based purely on sedimentological criteria, not stratigraphic position.

\section{Lithofacies 1 (LFC1): interbedded pelite and ripple-laminated psammite}

LFC1 is typified by massive pelite and semi-pelite interbedded with isolated tabular-layered micaceous psammite and ripple laminated psammite in beds $5-20 \mathrm{~cm}$ thick (Fig. 4a). Pelite and semi-pelite units comprise approximately $60 \%$ of the lithofacies. The pelite beds are mainly massive, but locally contain ripple lamination and flaser bedding. The micaceous psammite is composed of 50-55\% quartz, 20-25\% alkali and plagioclase feldspar and 15-20\% biotite and muscovite, and the micaceous composition imparts a grey hue to the rocks. No abrupt changes in lithology, bedform scale or gravel lags are observed in LFC1 and softsediment deformation is rare.

\section{Lithofacies 2 (LFC2): pelite, ripple-laminated and cross-bedded psammite}

LFC2 is characterised by decametre-scale coarsening-upward cycles (10-20 m thick) composed of pelite and semi-pelite interbedded with thin $(5-30 \mathrm{~cm}$ thick) isolated psammite beds at the base that progressively increase in number and thickness upward (Fig. 4b). These culminate in attaining a 50:50 proportion of psammite to pelite at the tops of these cycles, and pelite thickness decreases to $5-25 \mathrm{~cm}$. 
Psammite beds are tabular throughout LFC2, and typically display horizontal laminations or low-angle planar cross-stratification. The beds have large width-to-thickness ratios (20:0.3 m is typical), although these ratios should be treated as a minimum since individual outcrops are typically <30 m wide. In places hummocky cross-stratification is observed in beds typically 10-30 $\mathrm{cm}$ thick. Psammite beds at the tops of the coarsening-upward units often display planar cross-beds and asymmetric and combined-flow ripples (Fig. 5) exhibiting wavy- to rarely bimodal (herringbone) small ripple-scale cross-lamination. Cross-bed foresets at all scales are commonly accentuated by mud drapes throughout the LFC2 units.

Soft-sediment deformation is rare. Where observed, it shows pinched cuspate forms with greatest deformation at bed base. The soft-sediment features are almost always truncated by overlying beds and rarely affect more than two superposed beds.

\section{Lithofacies 3 (LFC3): interbedded, cross-bedded psammite and pelite}

LFC3 is characterised by well-developed, coarsening-upwards cycles 15-20 m thick consisting of low-angle cross-bedded, tabular psammite interbedded with a varying amount of pelite and semi-pelite (Fig. 6). In comparison to LFC1 and LFC2, LFC3 psammites are generally less micaceous (composed of $60-75 \%$ quartz, c. $30 \%$ plagioclase and alkali feldspar and $c .15 \%$ muscovite and biotite) and comprise a much larger (60-70\%) proportion of the depositional cycles.

LFC3 cycles typically show: a pelitic base (0.5-1.5 m thick); an upward increase in the number and thickness of psammite beds and concomitant reduction in pelite; and a predominantly psammitic top (Fig. 6). A sequential change of bedforms accompanies the lithological changes in each cycle: bases are characterised by bundles of semi-pelitic and psammitic flaser, lenticular and pinstripe bedforms (Fig. 7a); central parts display 5-15 cm thick tabular psammite beds that are interbedded with horizontal and wavy-laminated semipelite units ranging from 5 to $10 \mathrm{~cm}$ in thickness (Fig. 7b); and the uppermost parts show scalloped and erosive-based to tabular psammitic beds that, in places, contain trough crossstratification and only minor pelite. Rhythmic bundling, or alternation, of the pelite and psammite beds is developed locally as evident by varying bed thicknesses, and mud-drapes and ripple cross-lamination are abundant. Psammite beds are sharp-based and tabular throughout LFC3, and show large width-to-thickness ratios $(15:<0.2 \mathrm{~m}$ is typical). The 
thickness of psammite beds increases from $<5 \mathrm{~cm}$ at the base of LFC3 units to $30 \mathrm{~cm}$ at the top. Ripple bedforms in LFC3 units are varied and consist of asymmetric, symmetric and combined-flow ripples. In many instances superposed ripples show opposing directions of internal cross-laminae dip. Bundling is developed as repeated, deci-centimetre-scale alternations between ripple cross-lamination with mud drapes, and flat-laminated intervals with much lesser mud laminae (Fig. 7c).

In places, pinched, cuspate soft-sediment deformation features are observed within the thickest psammite beds in the upper parts of the LFC3 cycles. Throughout LFC3 there is no discernable change in the overall proportion of micaceous content of the beds or softsediment deformation.

\section{Lithofacies 4 (LFC4): gritty, cross-bedded psammite}

LFC4 facies develop upwards from LFC3 and are confined to the middle of the Crom Psammite Formation. Limited continuous outcrop between LFC3 and LFC4 hinders detailed and systematic documentation of the transition between the lithofacies but, nonetheless, sufficient outcrop is present (e.g. in the vicinity of Crom Loch above Gleann Mòr, Fig. 2c) over $c .1 \mathrm{~km}$ of stratigraphy to confirm that there is a consistent upward increase in trough cross-bedded psammite and a concomitant decrease in interbedded pelite.

In the vicinity of Crom Loch, LFC4 is composed predominantly of feldspathic to quartzitic psammite containing 50-60\% quartz, 30-35\% alkali and plagioclase feldspar and 5-10\% biotite and muscovite. Psammite constitutes more than $90 \%$ of LFC4 and is typified by amalgamated and stacked sets and cosets of trough cross-beds (Fig. 8), 5-50 cm thick, exhibiting erosive, scalloped bases and interbedded with much subordinate thin pelite beds (typically $<5 \mathrm{~cm}$ thick; Fig. 9a). The trough-cross bed sets define scours with a smaller widthto-thickness ratio (typically $30-50 \mathrm{~cm}$ wide and $4-15 \mathrm{~cm}$ thick) than in LFC1-3. The troughcross bed sets are marked by near angle-of-repose foresets that are tangential to bounding surfaces. Rarely, planar-stratified lenticular and wedge-shaped beds (lateral accretion bars) are present and range from 1.5-2 $\mathrm{m}$ in length and 20-40 cm thick. These bed dimensions are, however, treated as minimal values due to the erosional truncation of the bedforms by overlying beds. Lateral accretion features having set thicknesses measurable in decimetres 
can be observed and are orientated obliquely to the trough cross-beds and planarstratification.

Gravel clasts and gravel lags are abundant within the psammitic facies (Fig. 9a); cm-scale accessory mineral bands are present locally. Gravel clasts of quartz and K-feldspar are typically 2-3 $\mathrm{mm}$ diameter (with the largest clasts having c. $4 \mathrm{~mm}$ diameters), and normal grading is observed within individual trough-cross bed sets. Soft-sediment deformation is relatively common within the thickest sets and is generally restricted to individual beds. Softsediment deformation geometries are mainly pinched cuspate forms (Fig. 9b).

LFC4 exhibits fining-upward units 5-10 m thick (Fig. 8), in contrast to the coarseningupward trends typifying LFC1-3 lithofacies cycles. Each unit is characterised by amalgamated trough cross-bed co-sets at the base, and co-sets of trough cross-beds with associated ripple structures and minor pelite beds at the top. Coarsening-upward sequences are observed locally and display thin ripple structures interbedded with minor pelite (beds generally $1-10 \mathrm{~cm}$ thick) at the base, and amalgamated trough cross-beds (set thicknesses of 5$30 \mathrm{~cm}$ ) at the top. Bedforms throughout this lithofacies exhibit mud drapes (Fig. 9a).

In the vicinity of Beinn a'Cheistall (about $10 \mathrm{~km} \mathrm{SW}$ of the main study area; Fig. 2b), the proportion of coarse-grained material is significantly greater and clast sizes are conspicuously larger (Peach et al. 1912). Clasts are generally lenticular and flattened due to tectonic deformation, and apparent long-axis lengths of $4 \mathrm{~cm}$ are common. Clasts are mainly $\mathrm{K}$ feldspar, vein quartz and quartzite, indicative of a broadly granitic source area. Layers of conglomerate up to $50 \mathrm{~cm}$ thick are common and alternate with layers of trough cross-bedded psammite.

\section{Palaeoenvironmental interpretation}

\section{LFC1}

The high proportion of pelite, interbedded with sharp-based, tabular and thinly laminated psammitic and semi-pelitic beds is indicative of episodic deposition within a dominantly relatively low-energy environment. The occurrence of nested ripple-laminated and tabular psammite within mostly pelite and semi-pelite is indicative of unconfined sheet-like flows interspersed with quiescent periods. The rare occurrence of hummocky cross-stratification 
within LFC1 supports this interpretation and indicates the influence of storms during some depositional episodes (Hamblin \& Walker 1979; Walker 1992; Dumas \& Arnott 2006). This combination of features is typical of the offshore transition zone near storm wave base where mud deposition out of suspension would be punctuated by episodic, storm-related sandbearing currents forming ripple-laminated tabular beds and hummocky cross-stratification (Walker 1992; Varban and Plint 2008).

\section{LFC2}

The development of distinct coarsening-upward depositional units in LFC2 and an overall increase in psammitic facies indicates a shallower depositional environment, than LFC1 facies. The predominance of wave-ripples, planar cross-beds and bundled sets of ripple crosslamination to planar-lamination in the psammitic beds throughout most of LFC2 are indicative of sedimentation under oscillatory and combined flows in an inner shelf to shoreface setting (Walker 1992; Roberts 2007; Dashtgard et al. 2010). The occurrence of asymmetric and combined-flow ripples, bidirectional ripple sets and the prevalence of mud drapes in some of the LFC2 cycles indicate periodically reversing flows separated by repeated episodes of slack water. Such features are hallmark characteristics of tidally influenced shallow-marine environments (e.g. Walker 1992) and are good evidence for LFC2 deposition to have occurred under tidal currents for some periods of time (Roberts 2007; Varban \& Plint 2008).

Taken collectively, the LFC2 facies are indicative of deposition predominantly within a shallow-marine shoreface and inner shelf setting influenced by tides.

\section{LFC3}

Coarsening-upwards cycles consisting of greater proportions of psammite relative to interbedded pelite and psammite units is indicative of further shallowing of the depositional in LFC3. The presence of pinstripe, flaser and lenticular bedding, bidirectional ripple crosslamination and abundant mud drapes indicates that deposition was strongly tidally influenced (e.g. Molgat \& Arnott 2001; Roberts 2007; Varban \& Plint, 2008). The uppermost parts of LFC3 cycles are marked by psammites with sharp, scalloped, erosional bases and trough cross-bedding, reflecting deposition under increasingly higher energy flow conditions. The bundling of psammite and semi-pelitic beds within the LFC3 units suggests a 
palaeoenvironmental setting influenced by regular variations in flow energy, such as those associated with diurnal and spring-neap tidal cycles (Chakraborty \& Bose 1992; Molgat \& Arnott 2001). The thicker, cleaner, psammitic facies with mud drapes, erosional bases and trough cross-bedding at the top of LFC3 units do not display well-developed bed bundling, and our preferred interpretation is that they represent the distal-most parts of a distributary network of broad, shallow tidally-influenced channels.

\section{LFC4}

The erosive-based, stacked, amalgamated sets of trough cross-bed sets and co-sets, arranged in $\mathrm{m}$ - to several-m-thick units that show an upward decrease in grain-size and thinning of beds are characteristics attributable to deposition in fluvial channels (Cant \& Stockmal 2009; Varban \& Plint 2008; Roberts 2007). Such a trend is commonly interpreted as reflecting decreasing flow strength and gradual abandonment of channels (Cant \& Stockmal 2009; Bridge 1993; Skelly et al. 2003). The association of planar cross-stratified beds and the presence of gravel lags at the base of scalloped and lens-shaped beds with lateral accretion surfaces support such an interpretation.

The pinched, cuspate soft-sediment deformation features are interpreted to represent waterescape in rapidly deposited, water-logged sediment. Fluid escape is a consequence of high sedimentation rates generating unstable and over-pressurised water-laden sediment, for example during a flood event. A seismic origin of the soft-sediment deformation is ruled out because deformation is generally confined to individual beds (see Maltman, 1994).

Overall, LFC4 facies are interpreted as recording a tidally influenced, distal distributary network of multiple, shallow, laterally shifting channels (Nio \& Yang 1991; Varban \& Plint 2008; Walker 1992). Such a setting is typical of pre-land-plant Proterozoic times when channel margins were poorly stabilised (e.g. Bhattacharya \& Giosan 2003; Long 2006) and shorelines would probably have been characterised by a distributary network of numerous, unconfined shallow channels at any one time, a setting commonly referred to as a 'braidplain delta' (McPherson et al. 1987; Fedo \& Cooper 1990, 2001; Long 2006). As a result, there would not have been a discrete point-source input of sediment to the palaeoshoreline, as in many modern shorelines, and instead sediment delivery would have been along a continuous braidplain margin. The persistent repetition of coarsening- and thickening-upward units 
within LFC2-3 which underlie LFC4 in the lower part of the Crom Psammite Formation are taken as evidence of repeated marine flooding events followed by braidplain progradation.

\section{Facies associations}

The position of the lithofacies within the Crom Psammite Formation defines a coarseningand then fining-upwards facies succession. These trends are most easily recognised by the increasing and then decreasing psammite:pelite ratio upwards in the stratigraphy. Within the lower Crom Psammite Formation interbedded pelite and psammite lithologies of LFC1, develop upwards to the coarsening-upward lithofacies units of LFC2 and 3, in an overall coarsening-upwards facies succession. Across this succession there is an upward increase in the proportion of psammitic and tidally influenced facies in each depositional cycle. The top of the succession is marked by the predominantly psammitic and tidally-influenced distal fluvial facies of LFC4 - which are observed in the middle of the Crom Psammite Formation.

In the upper Crom Psammite Formation the lithofacies are superposed in reverse order, from LFC3 to LFC1, to define a fining-upward facies succession. Fluvial to tidally influenced lithofacies (LFC4-3) are, therefore, replaced upward by shoreface and shallow-marine lithofacies (LFC2-1) in the upper part of the Crom Psammite. Individual LFC1-3 units are very similar to those observed in lower Crom Psammite (Figs. 10 and 11), however, in the upper Crom Psammite the proportion of finer pelitic and semi-pelitic lithofacies systematically increases across each depositional cycle so that, on the whole, the upper Crom Psammite fines upward.

The lower and upper boundaries of the Crom Psammite Formation with the superposed Vaich Pelite and Diebidale Pelite formations, respectively, are indistinct. The contact between the the base of the Crom Psammite and the underlying Vaich Pelite appears gradational and is marked by an upward increase in the number of ripple laminated psammite beds interbedded with the pelite and semi-pelite. Similarly, the top of the Crom Psammite is composed predominantly of thinly laminated semi-pelite, and psammite is rare. As a result, the boundary between the Crom Psammite Formation and the laminated semi-pelitic Debidale Formation is also indistinct and difficult to place. 


\section{Stratigraphic trends: a complete synthesis of the Morar Group in northern Scotland}

The above analysis indicates that the Crom Psammite Formation is dominated by tidallyinfluenced, shallow-marine deposits with an incursion of braidplain facies in its middle part. There is evidence for two large-scale cycles: an initial marine-to-fluvial regression superceded by a fluvial-to-marine transgression in the upper part of the stratigraphy that culminated in a major basin-deepening event represented by the Diebidale Pelite Formation. Both the lower and upper contacts of the Crom Psammite are transitional and occur gradually over many $10 \mathrm{~s}$ of $\mathrm{m}$ of stratigraphic thickness. Non-marine facies are subordinate and restricted to a $c .1 \mathrm{~km}$-thick succession in the middle of the formation with the rest of the Crom Psammite being tidally-influenced shallow-marine deposits. The scarcity of threedimensional exposures of trough cross-beds means that only a paltry number (5) of reliable palaeocurrent measurements are available. For completeness, we note that they yield broadly $\mathrm{N}$-quadrant-directed sediment transport, but such few measurements over such a large stratigraphic thickness are not statistically significant. Nonetheless, these measurements are broadly parallel to the northeastward thinning of the coarse gravelly deposits within LFC4, which could also be taken as indicative of the direction of sediment transport.

The new data reported here need to be assessed in the context of published interpretations of the sedimentology of the lower (Altnaharra Formation) and middle (Glascarnoch Formation) parts of the Morar Group in northern Scotland (Krabbendam et al. 2008; Bonsor et al. 2010). These two publications documented a vertical facies transition from medial fluvial braidplain deposition, characterised by large (metre-scale) trough cross-bedded psammite in the Altnaharra Formation, to distal braidplain deposition, characterised by greater preservation of fines and smaller scale trough-cross beds and lateral accretion features, and then tidedominated shallow-marine deposition, reflected in rhythmic bundles of interbedded pelitic and psammitic lithologies, in the Glascarnoch Formation (Fig 12).

Our new findings for the upper part of the Morar Group, combined with this previously published data, therefore indicate that the Group is a transgressive succession over its $6-9 \mathrm{~km}$ thickness, marked by an upward and eastward increase in shallow-marine facies relative to fluvial facies (Fig. 12). Within this large-scale trend are two superposed 
progradation/retrogradation cycles, similar in scale to the late Proterozoic - early Cambrian Grand Cycles of the North America Cordillera (e.g. Aitken 1978). The first cycle is 3-6 km thick and was initiated with the progradation of proximal braidplain deposits of the basal Altnaharra Formation followed by a gradual fining-upward and backstepping phase of sedimentation through the fluvial to tidally influenced shoreline of the Glascarnoch Formation. This cycle culminated in the (meta)siltstone of the deeper marine Vaich Pelite Formation (Fig. 12). The second cycle started with a gradual regressive or forestepping system as marked by the return of tidally influenced shallow-marine deposition upward to distal braidplain deposition through the lower to middle part of the Crom Psammite Formation. The second cycle then ended with the resumption of the transgression, as shown by the initiation of a fining- and deepening-upward trend from the upper part of the Crom Psammite Formation into the pelitic Debiedale Formation (Fig. 12).

\section{Discussion}

This study, combined with Bonsor et al. (2010) and Krabbendam et al. (2008), shows that the Morar basin preserves two, $\mathrm{km}$-scale transgressive-regressive cycles superposed on an overall deepening trend with sufficient accommodation space for at least 6-9 $\mathrm{km}$ of siliciclastic sediment. Initial studies of the sedimentology of the Moine Supergroup interpreted it as a rift basin deposit (Strachan, 1986; Glendinning, 1988; Soper et al. 1998). Arguments against this interpretation have been summarised by Bonsor \& Prave (2008), Krabbendam et al. (2008) and Bonsor et al. (2010). Briefly, the Morar Group succession described here (Fig 12) lacks the hall-mark features of rift-basin successions: there is no evidence for the episodic emplacement of fault-generated detritus (all facies and lithological transitions are very gradual); there is no evidence for abrupt, periodic (i.e. repetitive) generation of accommodation space that would be expected along basin-bounding faults; nor are there any abrupt vertical or lateral facies transitions which are characteristic of rift basin settings (e.g. Archie \& López-Gómez 2005). Over c. 6-9 km of stratigraphy there is no indication of volcanic or evaporitic input, no substantial or abrupt coarse-grained deposits, and no rapid changes to the dominant palaeoflow direction, which is atypical of rift basin settings (e.g. Allen \& Allen 2005).

The alternative view adopted here is that the Morar Group was deposited in a foreland basin. The gradual and systematic nature of facies changes over significant thicknesses of sediment 
is consistent with an extensive basin formed by tectonic loading. This scenario can also explain the sustained subsidence necessary to accumulate such a thick succession, in combination with the general lack of syn-depositional igneous activity. Similar depositional frameworks, both in scale and lithofacies development, are known for the well-studied Cretaceous Interior Seaway basins that fringed the North American Cordillera from Canadian to Mexico (Beaumont, 1981; Flemings \& Jordan 1989; Cant \& Stockmal 1989; Flemings \& Jordan 1990; Jordan \& Flemings 1991; Underschultz \& Erdmer 1991; Plint et al. 2001; Varban \& Plint 2008; Yang \& Miall 2010). There, episodic loading events are known to have driven $\mathrm{km}$-scale progradational-retrogradational depositional cycles, not dissimilar to those described above for the Morar Group.

Palinspastic reconstructions of the Morar Group basin place it north of, but proximal to, the Grenville orogen in the North Atlantic region (Fig 1; Krabbendam et al. 2008; Cawood et al. 2010). Peak metamorphism in the Grenville is dated broadly at c. $1100-1000 \mathrm{Ma}$, with lateorogenic cooling and magmatism lasting until c. 960 Ma (e.g. Rivers 1997; Davidson 2008; Hynes \& Rivers 2010). Deposition of the Morar Group must have occurred after the age of the youngest dated detrital zircons at c. $1000 \mathrm{Ma}$ (Peters 2001; Friend et al. 2003; Kirkland et al. 2008) but before the oldest Knoydartian metamorphic event at c. 820 Ma (Vance et al. 1998). These age constraints permit the interpretation that deposition was at least partially contemporaneous with late-stage Grenville orogenesis. As a result, subsidence and progressive deepening of the basin could, at least in part, have been driven by loading of Grenville-orogeny-emplaced thrust sheets, and aided by sediment loading (e.g. Beaumont 1981). The gradual and systematic facies changes (both laterally and vertically) exhibited by the Morar Group and the lack of sharp influxes of coarse deposits are consistent with the genesis of the basin under a suite of conditions such that the rate of subsidence exceeded the rate of sediment flux, a pattern not uncommon in foreland settings (Tankard 1986; Varban \& Plint, 2008; Yang \& Miall 2010). The palaeocontinental reconstructions also indicate that the Moine basin was located relatively near to the periphery of Rodinia ( $\mathrm{Li}$ et al. 2008; see also Cawood et al. 2010), so that the evolving basin may also have been affected by far-field plate boundary effects and sea-level changes, similar to those which would have affected correlative successions in East Greenland and Svalbard (Cawood et al. 2010). The relative contributions of Grenville-related thrust loading versus plate boundary effects and/or eustatic sea-level rise to the basin evolution remain speculative however. 
High sediment flux from the Grenville orogen to the basin would have been facilitated by high erosion rates of the source, as a result of both a lack of sediment-stabilising terrestrial biota in the Neoproterozoic, and a humid climate (Williams 1969; Retallack \& Mindszenty 1994). The latter conditions have been inferred for at least the start of the deposition of the Morar Group from the nature of palaeosols found in Lewisian Gneiss beneath the baseTorridon Group unconformity in northwest Scotland by Williams (1969) and Retallack \& Mindszenty (1994). In addition, Hoffman \& Grotzinger (1993) suggested that the position of the Grenville Orogen was favourably oriented with respect to trade winds to allow monsoonal precipitation. The combination of high precipitation with a lack of vegetation has no parallels in modern-day orogens, so it is difficult to judge how much greater associated rates of erosion would have been, but it is likely that they were very high. The distribution of detritus derived from the Grenville orogen across Laurentia (Rainbird et al. 1992; Banks et al. 2007; Cawood et al. 2007; Petterson et al. 2009) suggests that a considerable portion of sediment bypassed the Grenvillian foreland sensu stricto. The gradual transitions between facies in the Morar Group are inferred to be the result of sustained delivery of sediment to the basin. If the higher estimates of sedimentation rates in Phanerozoic foreland basins are applicable - e.g. c. $500 \mathrm{~m} / \mathrm{Myr}$ (e.g. Pfiffner 1986; Roberts 2005), then the entire Morar Group may have been deposited within $12-18$ million years.

The fluvial sandstones of the early Neoproterozoic Torridon Group outcrop extensively on the Caledonian foreland in northern Scotland, west of the Moine Thrust Zone (Fig 12; Stewart 2002 and references therein). The possibility of correlation of the Torridon Group and the Morar Group has been discussed frequently (e.g. Peach et al. 1907; Kennedy 1951; Sutton \& Watson 1964; Stewart 2002; Friend et al. 2003), although it has often been discounted because of the potentially large displacements that may have occurred on the intervening Moine Thrust. Krabbendam et al. (2008) have shown that the Altnaharra Formation and the Torridon Group are similar in terms of their age of deposition, fluvial sedimentology, stratigraphical thickness and position on Lewisian basement, geochemistry, detrital zircon age pattern, and overall sediment transport direction (see also Rainbird et al. 2001; Kinnaird et al. 2007). The detrital zircon distributions in both groups show that they share a similar source, namely parts of eastern Laurentia and the Grenville Orogen, the final stages of which overlap deposition. It was therefore concluded that the Applecross-Aultbea and the Altnaharra formations are direct correlatives (Fig 12) and formed part of an axial 
trunk fluvial system flowing in front of the Grenville Orogen, forming an orogen-parallel foreland basin.

It is now apparent that both the Torridon Group and the lower Morar Group are characterised by major fining-upwards trends. In the Torridon Group this fining-upwards trend occurs within a terrestrial-fluvial succession - topped by deltaic and/or lacustrine deposits of the Cailleach Head Formation (Stewart 2002). Within the Morar Group - originally deposited much farther east - the trend is from medial fluvial to shallow marine facies. Our reconstruction of stratigraphic relations implies that the Applecross-Aultbea-Altnaharra fluvial wedge passed laterally eastwards into the dominantly tidally-influenced shallowmarine sediments of the Glascarnoch Formation (Fig 12). We interpret the base of the overlying Vaich Pelite Formation in the Morar Group as a major flooding surface produced during marine transgression; this unit may broadly correlate with the deltaic and/or lacustrine deposits of the Cailleach Head Formation (Stewart 2002) at the exposed top of the Torridon Group (Fig 12). Our new data for the upper Morar Group reveal that a further progradationalretrogradational cycle occurred, as recorded by the Crom Psammite, and then a major flooding surface represented by the base of the Diebedale Pelite Formation (Fig 12). Our proposed correlations require testing by geochronology centred on providing more accurate constraints on the ages of deposition of these units, as well as a more systematic study of detrital zircon age patterns than is available to date.

\section{Conclusions}

This study provides new sedimentological data for reconstructing the depositional framework of the Morar Group (lower Moine Supergroup) in northern Scotland. The Crom Psammite Formation, which forms the upper part of the Morar Group, is ca. 2-3 km thick and is exposed across its full thickness in the Glen Calvie area, northern Scotland. Detailed sedimentological analysis has identified:

- Four lithofacies within the Crom Psammite Formation, ranging from tidallyinfluenced shallow-marine, to fluvial deltaic facies. The non-marine facies are subordinate and restricted to a c. $1 \mathrm{~km}$-thick succession in the middle of the formation. 
- Vertical stacking of the facies define two large-scale cycles, each ca. 1-1.5 km thick: a coarsening-upward marine-to-fluvial regression in the lower Crom, and a finingupward fluvial-to-marine transgression in the upper part of the stratigraphy that culminated in a major basin-deepening event represented by the Diebidale Pelite Formation.

- Both the lower and upper contacts of the Crom Psammite to the Vaich and Debidale Pelite formations, respectively, are transitional and occur gradually over many 10 s of $\mathrm{m}$ of stratigraphic thickness.

Our new findings for the upper part of the Morar Group, combined with previously published data (Bonsor et al. 2010; Krabbendam et al. 2008), indicate that the Morar Group is a transgressive succession over its 6-9 km thickness, marked by an upward and eastward increase in shallow-marine facies relative to fluvial facies. Within this large-scale trend are two superposed progradation/retrogradation cycles, similar in scale (several $\mathrm{km}$ ) to the late Proterozoic - early Cambrian Grand Cycles of the North America Cordillera. The overall characteristics of the succession are consistent with deposition in a large, marginally underfilled foreland basin located adjacent to the Grenville orogen, and possibly linked to the peri-Rodinian ocean.

\section{Acknowledgements}

The authors would like to thank C. M. Fedo and an anonymous reviewer for their thorough and constructive comments to the paper. $\mathrm{HB}$ and MK publish with permission of the Executive Director of the British Geological Survey. 


\section{References}

AITKEN, J.D. 1978. Revised models for depositional grand cycles, Cambrian of the southern Rocky Mountains, Canada. Bull. Canadian Petroleum Geol. 26, 515-542.

Allen, P.A. \& Allen, J.R. 2005. Basin Analysis: Principles and Applications. Blackwell Publishing, London, $560 \mathrm{pp}$.

ARCHE, A. \& LÓPEZ-GómEZ, J. 2005. Sudden changes in fluvial style across the Permian Triassic boundary in eastern Iberian Ranges, Spain: analysis of possible causes. Palaeography, Palaeoclimatology, Palaeoecology, 229; 104-126.

Banks, C.J., Smith, M., Winchester, J.A. Horstwood, M.S A., Noble, S.R. \& OtTley, C.J. 2007. Provenance of intra-Rodinian basin fills; the lower Dalradian 463 Supergroup, Scotland. Precambrian Research, 153(1-2), 46-64.

BEAUMONT, C. 1981. Foreland basins: Royal Astronomical Society Geophysical Journal, 65; 291329.

BHATTACHARYA, J. P. \& GIOSAN, L. 2003. Wave-influenced deltas: geomorphical implications for facies reconstruction, Sedimentology, 50; 187-210.

BIJU-DUVAL, B. 2002. Sedimentary Geology: sedimentary basins, depositional environments and petroleum formation, French Institute of Petroleum Publications, Technip, Paris, pp 129-161.

Bonsor, H. C. \& PRAVE, A. R. 2008. The Upper Morar Psammite of the Moine Supergroup, Ardnamurchan Peninsula, Scotland: depositional setting, tectonic implications, Scottish Journal of Geology, 44; 2; 1-12.

Bonsor, H. C., Strachan, R. S., Prave, A. R. \& Krabbendam, M. 2010. Fluvial braidplain to shallow marine transition in the early Neoproterozoic Morar Group, Fannich Mountains, northern Scotland, Precambrian Research, 183; 791-804.

BRIDGE, J.S., 1993. The interaction between channel geometry, water flow, sediment transport and deposition in braided rivers. In: J.L. Best and C.S. Bristow (Eds), Braided Rivers. Geological Society, London, Special Publication, 75, 13-71.

CANT, D.J. \& STOCKMAL, G.S. 1989. The Alberta foreland basin: relationship between stratigraphy and Cordilleran terrane-accretion events. Canadian Journal of Earth Sciences, 26; p. 1964-1975.

CANT, D.J. \& Stockmal, G.S. 2009. Some controls on Sedimentary Sequences in Foreland Basins: examples for the Alberta Basin, in Frostick, L. E. \& Steel, R. J. (eds) Tectonic controls and signitures in sedimentary basins, p. 49-65.

CAwood, P.A., Nemchin, A.A., StRaChan, R., KinNy, P. \& LOEWy, S. 2004. Laurentian provenance and an intracratonic tectonic setting for the Moine Supergroup, Scotland, constrained by detrital zircons from the Loch Eil and Glen Urquhart successions. Journal of the Geological Society, London, 161; 861-874.

Cawood, P.A., Nemchin, A.A., Strachan, R.A., Prave, A.R., \& Krabbendam, M. 2007. Sedimentary basin and detrital zircon record along East Laurentia and Baltica during assembly and breakup of Rodinia, Geological Society of London Journal, 164; 257-275. 
Cawood, P. A., Strachan, R. A., Cutts, K., Kinny, P. D., Hand, M. \& Pisarevsky, S. 2010. Neoproterozoic orogeny along the margin of Rodinia: Valhalla Orogen, North Atlantic, Geology, 38; 99-102.

ChAKRABORTY, C. \& BOSE, P. K. 1992. Rhythmic shelf storm beds: Proterozoic Kalmur Formation, India, Sedimentary Geology, 77; 3-4, 259-268.

Cutts, K. A., Kinny, P. D., Strachan, R. A., HAND, M., Kelsey, E. E., EMERY, M., Friend, C. R. L. and LESLIE, A. G. 2010. Three metamorphic events recorded in a single garnet: integrated phase modelling, in situ LA_ICPMS and SIMS geochronology from the Moine Supergroup, NW Scotland, Journal of Metamorphic Geology, 28; 249-267.

Dashtgard, S. E., MacEachem, J. A., Frey, S. E. and Gingras, M. K. 2010. Tidal effects on the shoreface: Towards a conceptual framework, Sedimentary Geology, doi: 0.1016/j.sedgeo.2010.09.006

DALZIEL, I.W.D. \& SOPER, N.J., 2001. Neoproterozoic extension on the Scottish promontory of Laurentia: Paleogeographic and tectonic implications. Journal of Geology, 109; 299-317.

DAVIDSON, A., 2008. Late Paleoproterozoic to mid-Neoproterozoic history of northern Laurentia; an overview of central Rodinia. Precambrian Research, 160; 5-22.

DeVlin, W. J., RudolPh, K. W., Shaw, C. A., \& EhMAN, K. D. 1993. The effect of tectonic and eustatic cycles on accommodation and sequence-stratigraphic framework in the Upper Cretaceous foreland basin of southwestern Wyoming, in Posamentier, H. W., Summerhayes, C. P, Haq, B. U. And Allen, G. P. (eds) Sequence stratigraphy and facies associations: International Association of Sedimentologists, Special Publication, 18, London, Blackwell Scientific Publisher.

DUMAS, S. \& ARNOTT, R. W. C. 2006. Origin of hummocky and swaley cross-stratification - The controlling influence of unidirectional current strength and aggradation rate, Geology, 34; 12, 1073 1076.

FEDO, C.M. \& COOPER, J.D. 1990. Braided fluvial to marine transition; the basal Lower Cambrian Wood Canyon Formation, southern Marble Mountains, Mojave Desert, California, Journal of Sedimentary Research, 60; 220-234.

FEDO, C.M. \& COOPER, J.D. 2001. Sedimentology and sequence stratigraphy of Neoproterozoic and Cambrian units across a croton-margin hinge zone, southeastern California, and implications for the early evolution of the Cordilleran margin, Sedimentary Geology, 141-142; 501-522.

FLEMINGS, P.B. \& JoRdAN, T.E. 1989. A Synthetic Stratigraphic Model of Foreland Basin Development, Journal of Geophysical Research, 94; 3851-3866.

FLEMINGS, P.B. \& JORDAN, T.E. 1990. Stratigraphic Modeling of Foreland Basins: Interpreting Thrust Deformation and Lithosphere Rheology, Geology, 18; 430-434.

FRIEND, C. R. L., STRACHAN, R. A. \& KinNY, P. D. 2008. U-Pb zircon dating of basement inliers within the Moine Supergroup, Scottish Caledonides: implications of Archean protolith ages, Journal of the Geological Society of London, 165; 807-815.

FRIEND, C. R. L., STRACHAN, R., KINNY, R. D. \& WATt, G. R. 2003. Provenance of the Moine Supergroup of NW Scotland: evidence from geochronology of detrital and inherited zircons from (meta)sedimentary rocks, granites, and migmatites. Journal of the Geological Society, London, 160; 247-257. 
GLENDINNING, N. R. W. 1988. Sedimentary structures and sequences within a Late Proterozoic tidal shelf deposit: the Upper Morar Psammite Formation of northwestern Scotland, in: Winchester, J. A. (ed), Later Proterozoic Stratigraphy of the Northern Atlanic Regions, , Blackie, Chapman and Hall, 531.

HAMBlin, A. P. \& WALKER, R. G. 1979. Storm-dominated shallow marine deposits: the FernieKootenay (Jurassic) transition, southern Rocky Mountains, Canadian Journal of Earth Science, 16; 9 , 1673-1690.

HofFMAN, P.F., 1991. Did the Breakout of Laurentia turn Gondwanaland inside out? Science, 252; 1409-1412.

HOFFMAN, P. F. \& GROTZINGER, J. P. 1993. Orographic precipitation, erosional unloading, and tectonic style, Geology, 21; 3, 195-198.

HOLDSWORTH, R.E., STRACHAN, R.A. \& HARRIS, A.L. 1987. The stratigraphy, structure and regional significance of the Moine Rocks of Mull, Argyllshire, W. Scotland. Geological Journal, 22; 83-107.

HOLDSWORTH, R. E. 1989. The geology and structural evolution of the a Caledonian fold and ductile thrust zone, Kyle of Tongue region, Sutherland, northern Scotland, Journal of the Geological Society of London, 146; 809-823.

HyNeS, A. \& RiVERS, T. 2010. Protracted continental collision - evidence from the Grenville Orogen, Canadian Journal of Earth Sciences, 47; 591-620.

JORDAN, T.E. \& FLEMINGS, P.B. 1991. Large scale stratigraphic architecture, eustatic variation and unsteady tectonism: a theoretical evaluation. Journal of Geophysical Research, 96; 6681-6699.

KENNEDY, W.Q. 1951. Sedimentary differentiation as a factor in the Moine-Torridonian correlation. Geological Magazine, 88; 257-266.

Kinnaird, T.C., Prave, A., Kirkland, C.L., Horstwood, M., Parrish, R., \& Batchelor, R.A., 2007. The late Mesoproterozoic-early Neoproterozoic tectonostratigraphic evolution of NW Scotland: the Torridonian revisited, Journal of the Geological Society of London 164; 541-551.

Kirkland, C. L, Strachan, R. A. \& PraVe, A. R. 2008. Detrital zircon signature of the Moine Supergroup, Scotland: contrasts and comparisons with other Neoproterozoic successions within the circum-North Atlantic region, Precambrian Research, 163; 332-350.

Krabbendam, M., Prave, A.R., \& Cheer, D., 2008. A fluvial origin for the Neoproterozoic Morar Group, NW Scotland; implications for Torridon - Morar group correlation and the Grenville Orogen Foreland Basin, Journal of the Geological Society, London, 165; 379-394.

Krabbendam, M., Strachan, R. A., Leslie, A. G., Goodenough, K. M. \& Bonsor, H. C. 2011. The internal structure of the Moine Nappe Complex and the stratigraphy of the Morar Group in the Fannichs - Beinn Dearg area, NW Highlands. Scottish Journal of Geology.

Li, Z.X., Bogdanova-Svetlana, V., Collins, A.S., Davidson, A., De Waele, B., ERnst, R.E., Fitzsimons, I.C.W., FuCK, A., GladKOChub, D.P., JacOBS, J., KARLSTROM, K.E., LU, S., Natapov, L.M., Pease, V., Pisaresvky, S.A., Thrane, K.,\& Vernikovsky, V., 2008. Assembly, configuration, and breakup history of Rodinia; a synthesis. Precambrian Research, 150; 179-210.

LONG, D.G.F., 2006. Architecture of pre-vegetation sandy-braided perennial and ephemeral river deposits in the Palaeoproterozoic Athabasca Group, northern Saskatchewan, Canada as indicators of Precambrian fluvial style. Sedimentary Geology, 90; 71-95. 
Maltman, A., 1994. Prelithification Deformation. In: P.L. Hancock (Ed), Continental Deformation. Pergamon Press, 143-158.

MCPherson, J. G., Shanmugam, G. \& Moiola, R. J. 1987. Fan-deltas and braid deltas: Varieties of coarse-grained deltas, GSA Bulletin, 99; 3, 331-340.

Molgat, M. \& ARNOTT, R. W. C. 2001. Combined tide and wave influence on sedimentation patterns in the Upper Jurassic Swift Formation, south-eastern Alberta, Sedimentology, 48; 1353-1369.

NiO, S.D. \& YANG, C.S. 1991. Diagnostic attributes of clastic tidal deposits: a review. In: Clastic Tidal Sedimentology (Eds D.G. Smith, G.E. Reinson, B.A. Zaitlin and R.A. Rahmani), Canadian Society of Petroleum Geology Memoirs, 16; 3-28.

Peach, B. N., Gunn, W., Clough, C. T., Hinxman, L. W., Crampton, C. B., Anderson, E. M. \& FLETT, J. S. 1912. The geology of Ben Wyvis, Carn Chuinneag, Inchbae and the surrounding country, Memoirs of the Geological Survey of Great Britain.

Peach, B.N., Horne, J., Gunn, W., Clough, C.T., HinXman, L.W. \&Teall, J.J.H. 1907. The geological structure of the North-West Highlands of Scotland. Memoirs of the Geological Survey of Great Britain.

PETERS, D. 2001. A geochemical and geochronological assessment of the Great Glen Fault as a terrane boundary. PhD Thesis (unpublished), University of Keele.

Pettersson, C.H., PeAse, V.,\& FreI, D., 2009. U-Pb zircon provenance of metasedimentary basement of the Northwestern Terrane, Svalbard: Implications for the Grenvillian-Sveconorwegian orogeny and development of Rodinia. Precambrian Research, 175; 206-220.

PFIFFNER, O.A., 1986. Evolution of the North Alpine foreland basin in the Central Alps. In: Allen, P.A. \& Homewood, P. (eds) Foreland Basins. International Association of Sedimentologists, Special Publications, 8, 219-228.

PLINT, A.G. 1997. Marine and nonmarine systems tracts in fourth order sequences in the EarlyMiddle-Cenomanian, Dunvegan Alloformation, northeastern British Columbia, Canada. In: High Resolution Sequence Stratigraphy: Innovations and Applications (Eds J. Howell and J.D. Aitken), Geological Society London Special Publication, 104; 159-191.

Plint, A. G., MCCARThY, P. J. \& FACCINI, U. F. 2001. Nonmarine Sequence stratigrpahy: Updip expression of sequence boundaries and systems tracts in a high resolution framework, Cenomanian Dunvegan Formation, Alberta Foreland Basin, Canada, AAPG Bulletin, 85; 11, 1967-2001.

RAINBIRD, R.H., HEARNAN, L. M. \& YounG, G.M. 1992. Sampling Laurentia: Detrital zircon geochronology offers evidence for an extensive Neoproterozoic river system originating from the Grenville orogen, Geology, 20; 4, 351-354.

RAINBIRD, R.H., HAMILTON, M.A. \& YOUNG, G.M. 2001. Detrital zircon geochronology and provenance of the Torridonian, NW Scotland. Journal of the Geological Society, London, 158; 15-27.

RAMSAY, J. G. 1957. Moine-Lewisian relations at Glenelg, Inverness-shire, Quaternary Journal of the Geological Society of London, 113; 487-523.

Retallack, G. J. and MindszenTy, A. 1994. Well preserved late Precambrian Paleosols from Northwest Scotland, Journal of Sedimentary Research, 64; 2a, 264-281. 
RIVERS, T., 1997. Lithotectonic elements of the Grenville Province; review and tectonic implications. Precambrian Research, 86; 117-154.

ROBERTS, E.M., 2005. Stratigraphic, taphonomic and paleoenvironmental analysis of the Upper Cretaceous Kaiparowits Formation, Grand Staircase-Escalante National Monument, Southern Utah [unpublished P.h.D dissertation]. University of Utah, Salt Lake City, 243 p

ROBERTS, E. M. 2007. Facies architecture and depositional environments of the Upper Cretaceous Kaiparowits Formation, southern Utah, Sedimentary Geology, 197; 207-233.

SKELLY, R.L., BRISTOW, C.S., \& ETHRIDGE, F.G., 2003. Architecture of channel-belt deposits in an aggrading shallow sandbed river: the lower Niobara River, northeast Nebraska. Sedimentary Geology, 158; $249-270$.

Sønderholm, M., Frederikson, K. S., SMith, M. P. \& TiRsgaARd, H. 2008. Neoproterozoic sedimentary basins with glacigenic deposits of the East Greenland Caledonides. In: Higgins, A. K., Gilotti, J. A. \& Smith, M. P. (eds) The Greenland Caledonies, Geological Society of America Memoir, 202; 99-136.

SOPER, N.J., HARRIS, A.L., \& STRACHAN, R.A., 1998. Tectonostratigraphy of the Moine Supergroup; a synthesis. Journal of the Geological Society of London, 155; 13-24.

Stewart, A.D., 2002. The Later Proterozoic Torridonian Rocks of Scotland: their Sedimentology, Geochemistry and Origin. Geological Society London Memoir, 24, 130 pp.

StRaCHAN, R. A. 1986. Shallow-marine sedimentation in the Proterozoic Moine Succession, northern Scotland, Precambrian Research, 32; 17-33.

Strachan, R., Smith, M., Harris, A. L. \& FetTes, D. J. 2002. The Northern Highland and Grampian terranes. In: Trewin, N. H. (eds). The Geology of Scotland. The Geological Society, London, 81-147.

Strachan, R. A., Holdsworth, R. E., Krabbendam, M. \& Alsop, G. I. 2010. The Moine Supergroup of NW Scotland: insights into the analysis of polyorogenic supracrustal sequences. In: Law, R., Butler, R. W. H., Holdsworth, R. E., Krabbendam, M., Strachan, R. A. (Eds.), Continental Tectonics and Mountain Building: The Legacy of Peach and Horne. Geological Society, London, Special Publication, 335; 231-252.

SutTON, J. \& WATSON, J. 1954. The structural and stratigraphic succession of Fannich Forest and Strath Bran, Ross-shire, Quarterly Journal of the Geological Society of London, 110; 21-54.

SutTon, J. \& WATSON, J. 1964. Some aspects of Torridonian stratigraphy in Skye. Proceedings of the Geologist's Association. 75; 251-289.

TANKARD, A.J. 1986. On the depositional response to thrusting and lithospheric flexure: examples from the Appalachian and Rocky Mountain basins. In: Foreland Basins (Eds P.A. Allen and P. Homewood), Int. Assoc. Sedimentology, Special Publication, 8; 369-392.

Undershultz, J.R. \& ERDMER, P. 1991. Tectonic loading in the Canadian Cordillera as recorded by mass accumulation in the foreland basin. Tectonics, 10; 367-380

VANCE, D, STRACHAN, R.A. \& JONES, K.A. 1998. Extensional versus compressional settings for metamorphism: Garnet chronometry and pressure-temperature-time histories in the Moine Supergroup, northwest Scotland. Geology. 26; 927-930. 
VARBAN, B. L. \& PLINT, A. G. 2008. Palaeo-environments, palaeogeography, and physiography of a large, shallow, muddy ramp: Late Cenomanian-Turonian Kaskapau Formation, Western Canada foreland basin, Sedimentology, 55; 201-233.

WALKER, R.G. 1992. Wave and storm-dominated shallow marine systems. In: Facies ModelsResponse to Sea Level Change (eds R.G. Walker and N.P. James), pp 219-238, Geological Association of Canada.

WILLIAMS, G.E., 1969. Characteristics and origin of a Precambrian pediment. Journal of Geology, 77; 183-207

WILSON, D.\& SHEPHARD, J. 1979. The Carn Chuinneag granite and its aureole. In Harris, A. L., Holland, C. H. and Leake, B. E. (eds) The Caledonides of the British Isles-Reviewed. Geological Society London, Special Publications, 8; 669-675.

YANG, Y. \& MiALL, A. D. 2010. Migration and stratigraphic fill of an underfilled foreland basin: Middle-Late Cenomanian Belle Fourche Formation in southern Alberta, Canada, Sedimentary Geology, 227; 51-64. 


\section{Figures}

Fig. 1. Schematic reconstructions of Laurentia, Baltica and Amazonia at ca. $1000 \mathrm{Ma}$, following amalgamation of Rodinia and Grenville-age orogenesis: (a) after Dalziel and Soper (2001) and (b) after Li et al. 2008 and Cawood et al. 2010, who used the term 'Asgard Sea' to refer to the oceanic tract that separated Laurentia and Baltica. Approximate position of Morar (M), Torridon (T), and Krummedal (K) sequences is indicated. SN, Sveconorwegian Belt; Hb, Hebridean block (NW Scottish Foreland and Rockall Platform).
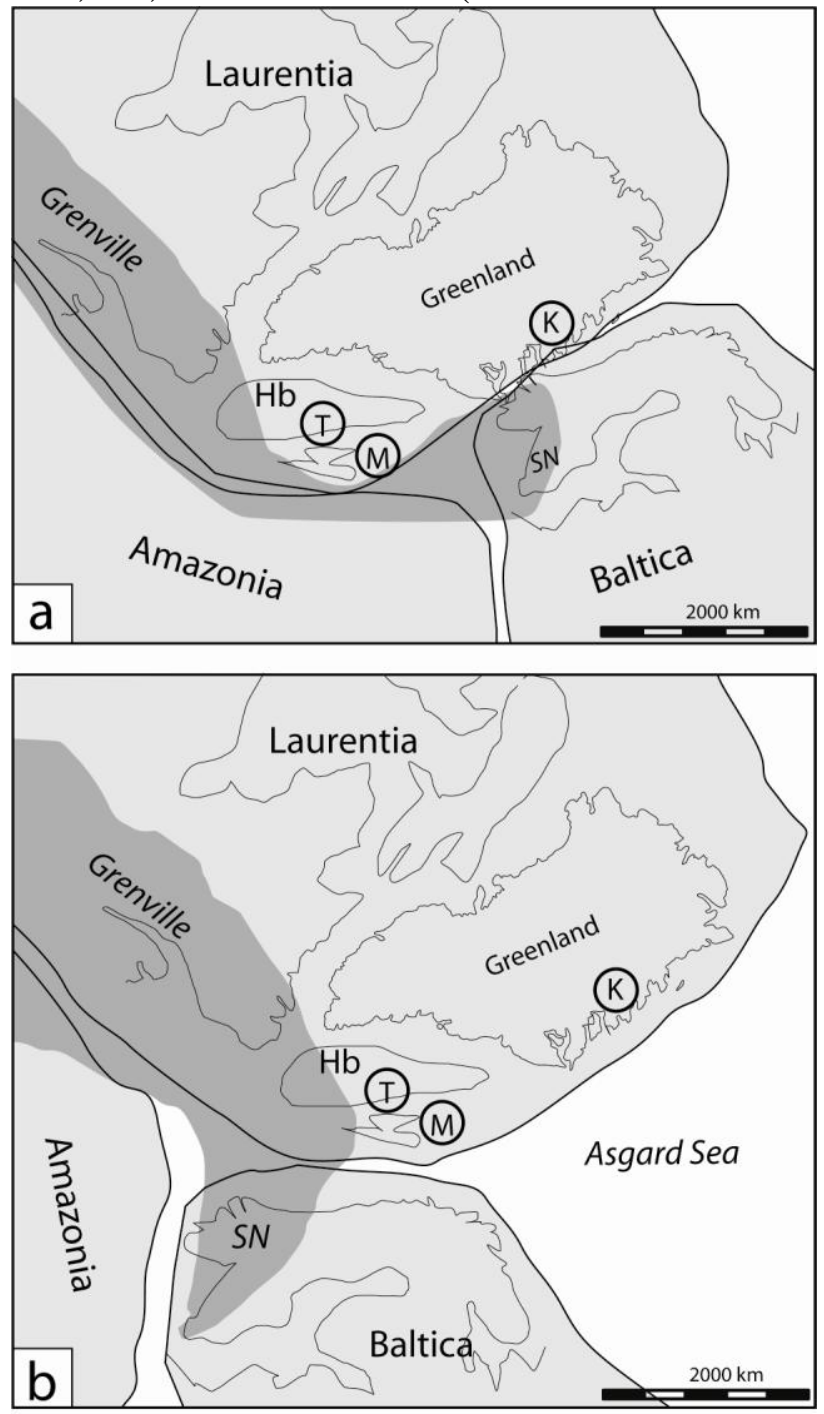
Fig. 2. a) Overview map of Northern Highlands, showing main early Neoproterozoic sequences and their basement. Post-900 Ma rocks not shown. AT $=$ Achness Thrust, $\mathrm{MT}=$ Moine Thrust, SBT $=$ Sgurr Beag Thrust, MP $=$ Morar Peninsula. Areas of previous sedimentological studies in the lower and middle Morar Group are outlined within boxes marked 'Fannichs' (Bonsor et al. 2010) and 'Sutherland' (Krabbendam et al. 2008). Box marked 'Glen Calvie' is area of this study; b) Map of the Glen Calvie area - subset area highlighted is shown in Fig. 2c; c) Geological map of Glen Calvie study area. Location of sedimentological logs from this study are shown: U.G.-V. = Upper Glascarnoch - Vaich Pelite - Lower Crom Psammite; L.C. = Lower-Mid Crom Psammite; M.C. = Mid Crom Psammite; U.C. $=$ Upper Crom Psammite section. Aproximate boundaries of lithofacies LFC1 - LFC4 shown.

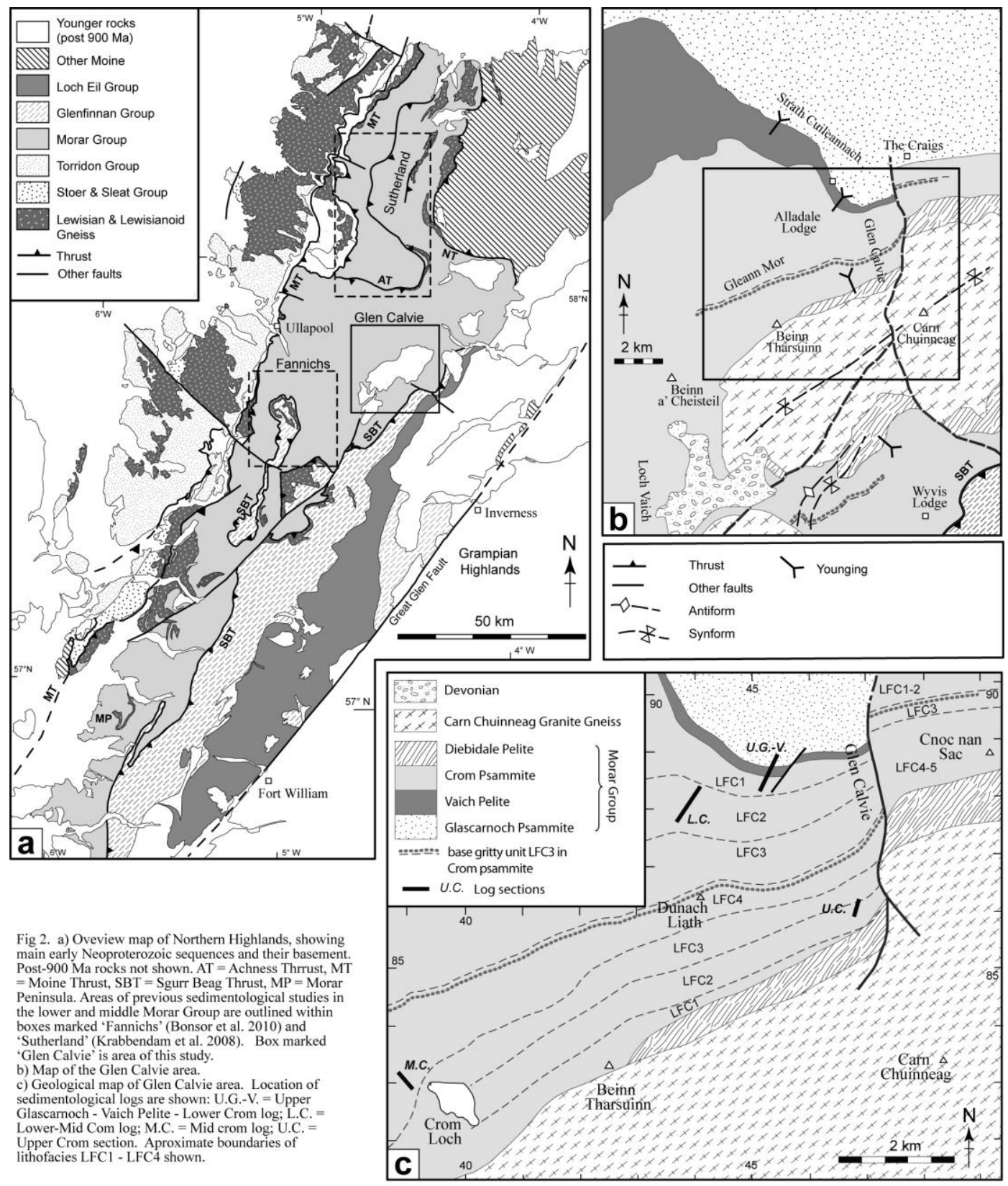


Fig. 3. Schematic diagram of the regional Morar Group tectono-stratigraphy in the northern Highlands (Fannichs - Sutherland). Major thrust faults, but not folds, are shown; not to scale. Relative location of log sections from this study are denoted by black bars - the code of the logs corresponds to logs marked in Fig. 2, and to the detailed log sections in Figs. 4, 6, $8 \&$ 10. Log sections from previous studies are shown by white bars (Bonsor et al. 2010), and hashed bars (Krabbendam et al. 2008).

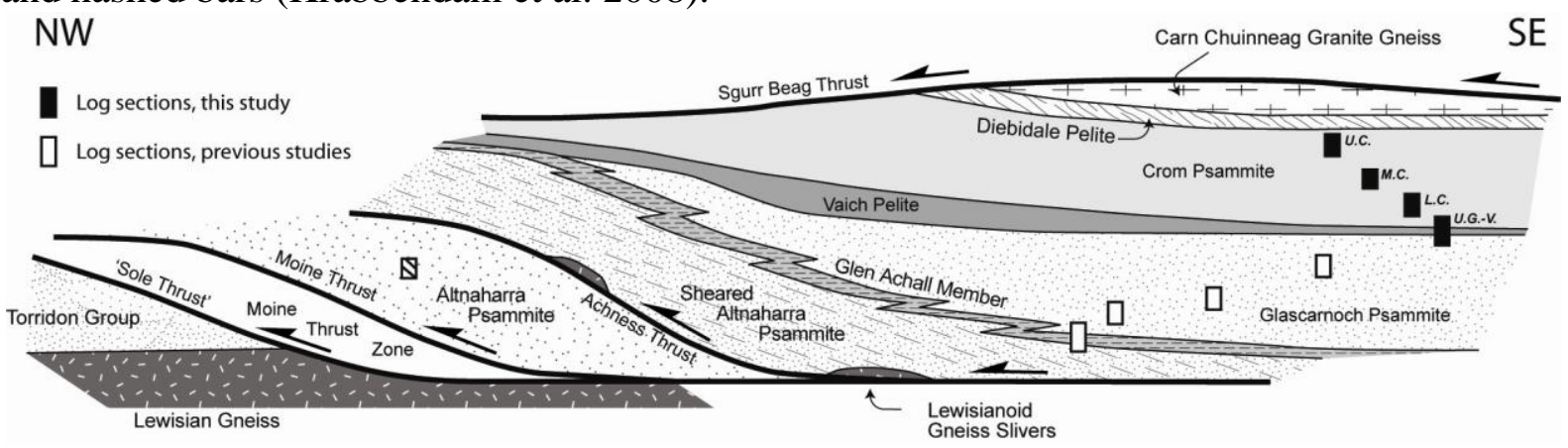


Fig. 4. (a) Sedimentological log of LFC1 in the lower part of the Crom Psammite Formation (GR 245314, 888506); and (b) sedimentological log of LFC2 above LFC1 in the lower Crom Psammite Formation (GR 243957, 888050). In both, arrows denote palaeo-flow directions measured from small-scale ripples; note the absence of conglomerate. Grey triangles mark coarsening-upward units.
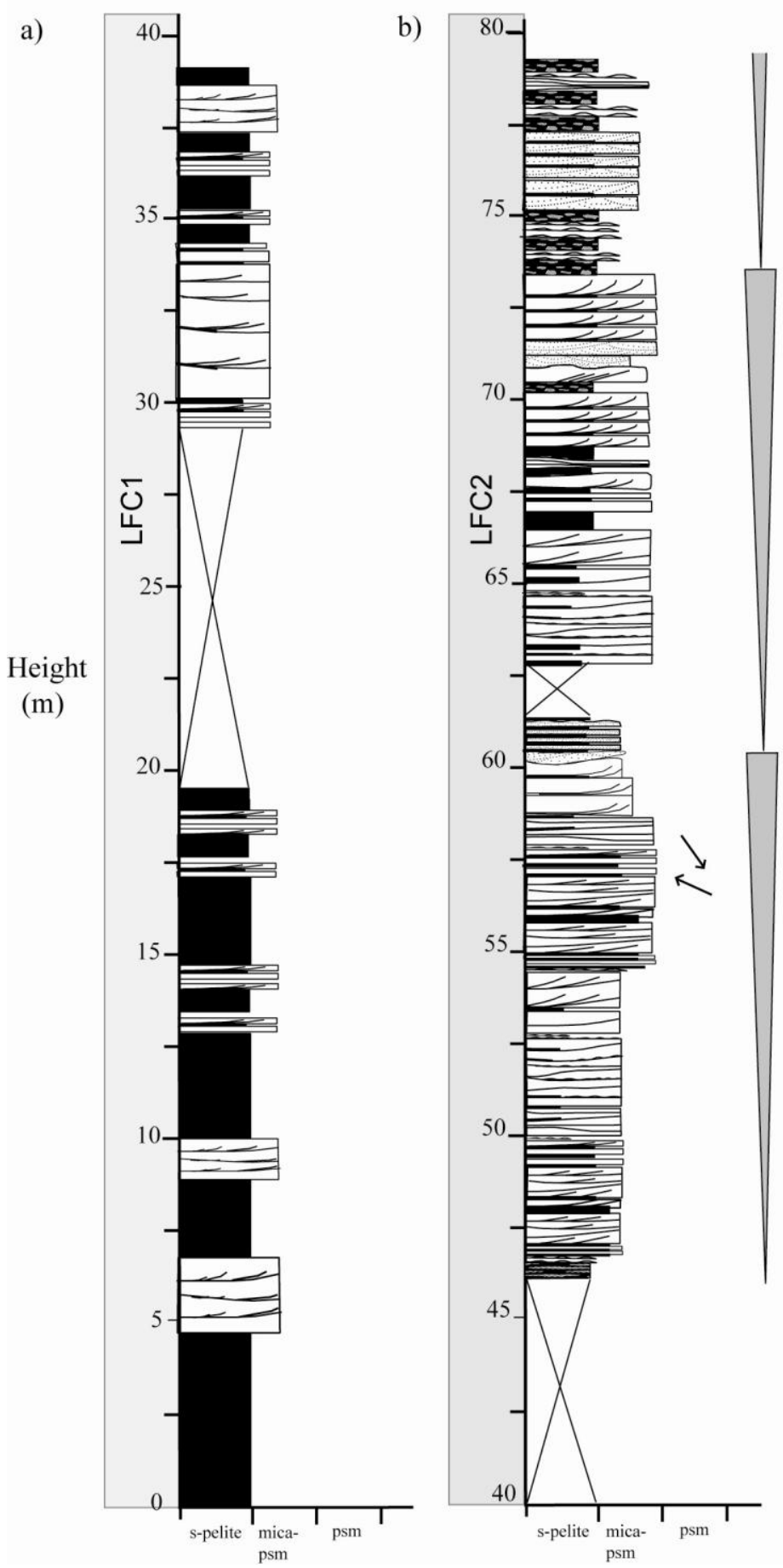
Fig. 5. Complex co-sets of ripple cross-laminations within psammitic beds of the Lower Crom Formation.

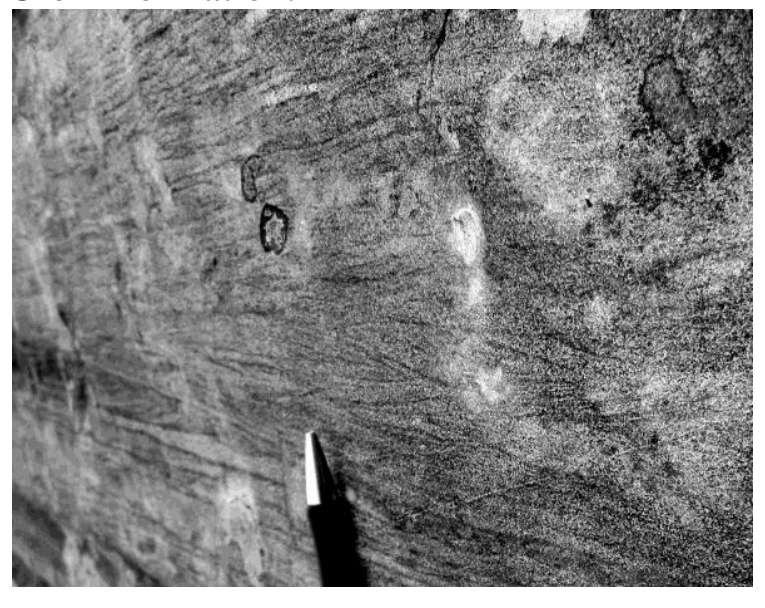


Fig. 6. Sedimentological log of LFC3 in the lower part of the Crom Psammite Formation, Glen Calvie. Arrows denote palaeo-flow directions measured from small-scale ripples; grey triangles mark coarsening-upward units.
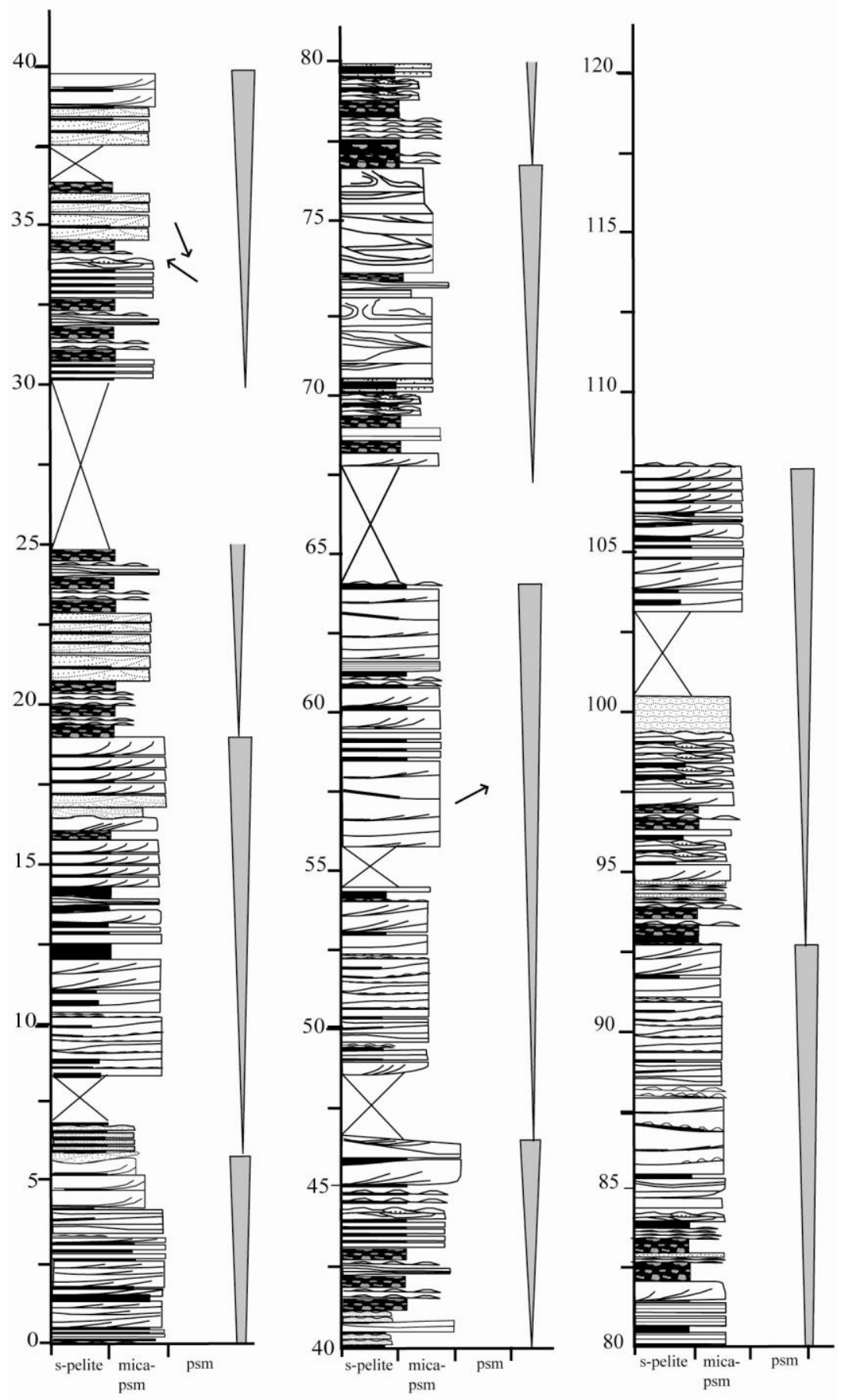
Fig. 7. Photographs of the lower part of the Crom Psammite Formation: (a) lenticular and flaser bedding; (b) thin tabular cross-beds and lens-shaped psammite beds interbedded with horizontal and wavy-laminated semi-pelite units; and (c) bundles of combined-flow and wave-ripple units with planar laminated units.

a
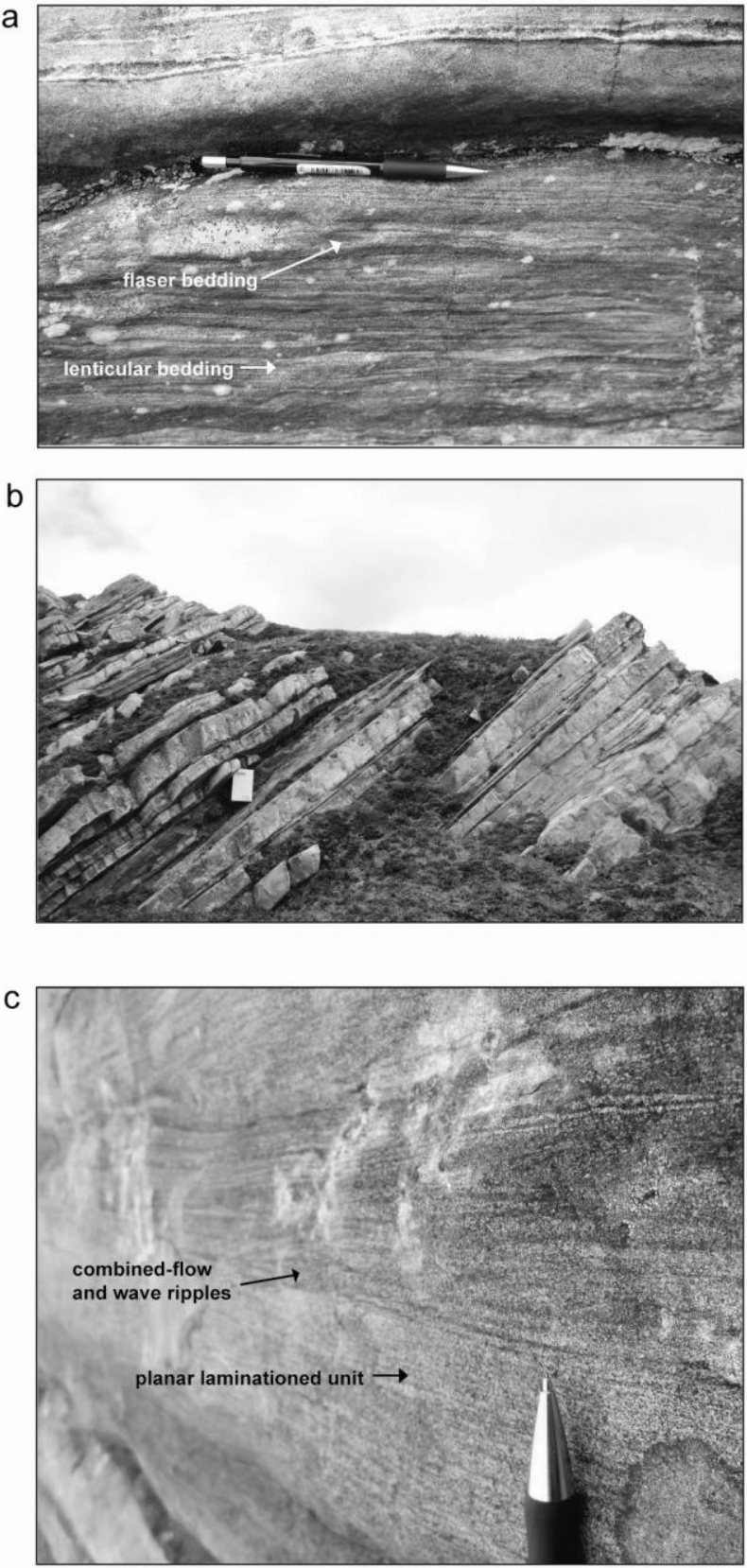
Fig. 8. Sedimentological log of LFC4 within the middle part of the Crom Psammite Formation, Crom Loch (GR 238995, 882705). Arrows denote palaeo-flow directions measured from three-dimensional trough cross-bed structures; dots denote gravel lags and clasts; grey triangles mark fining-upward units.

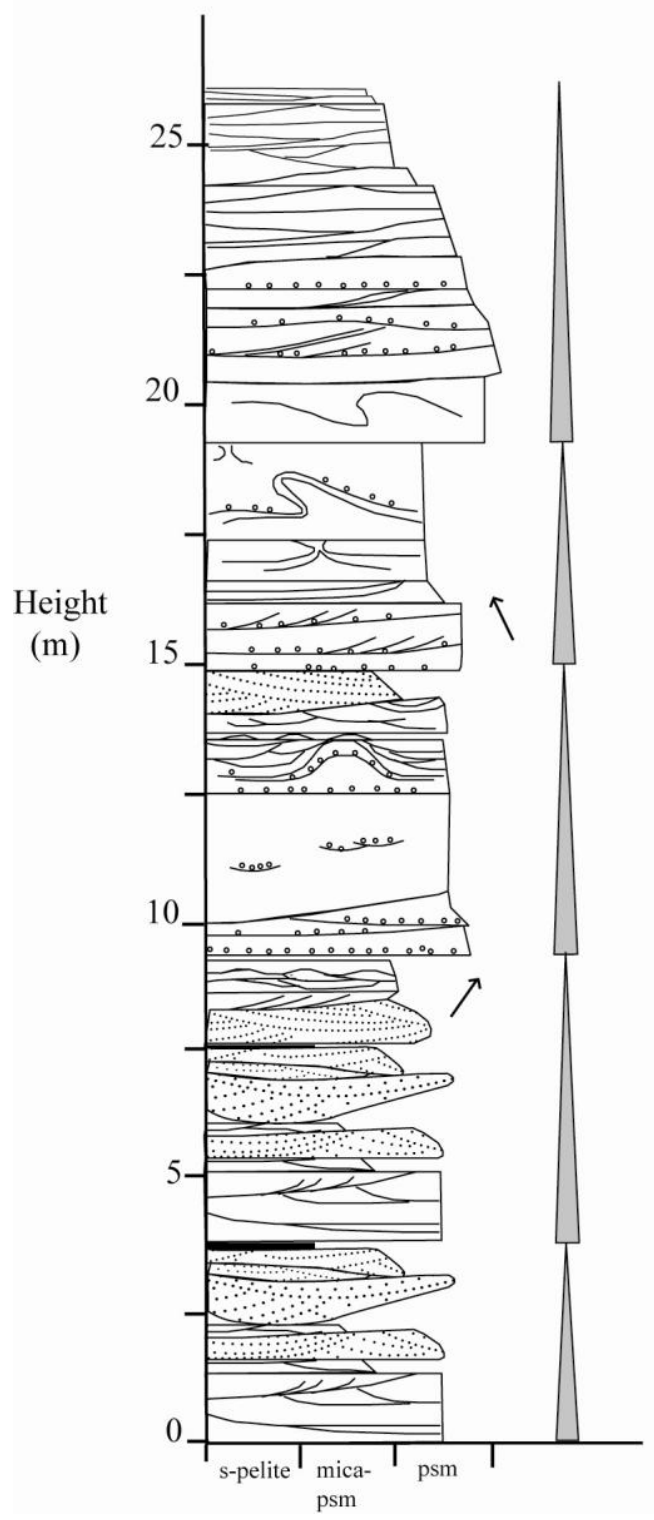


Fig. 9. Photographs illustrating the LFC4 lithofacies within the middle part of the Crom Psammite Formation: (a) gravel lags and mud drapes are common at the base and top of individual cross-bed sets; and (b) typical pinched cuspate soft-sediment deformation forms in LFC3.
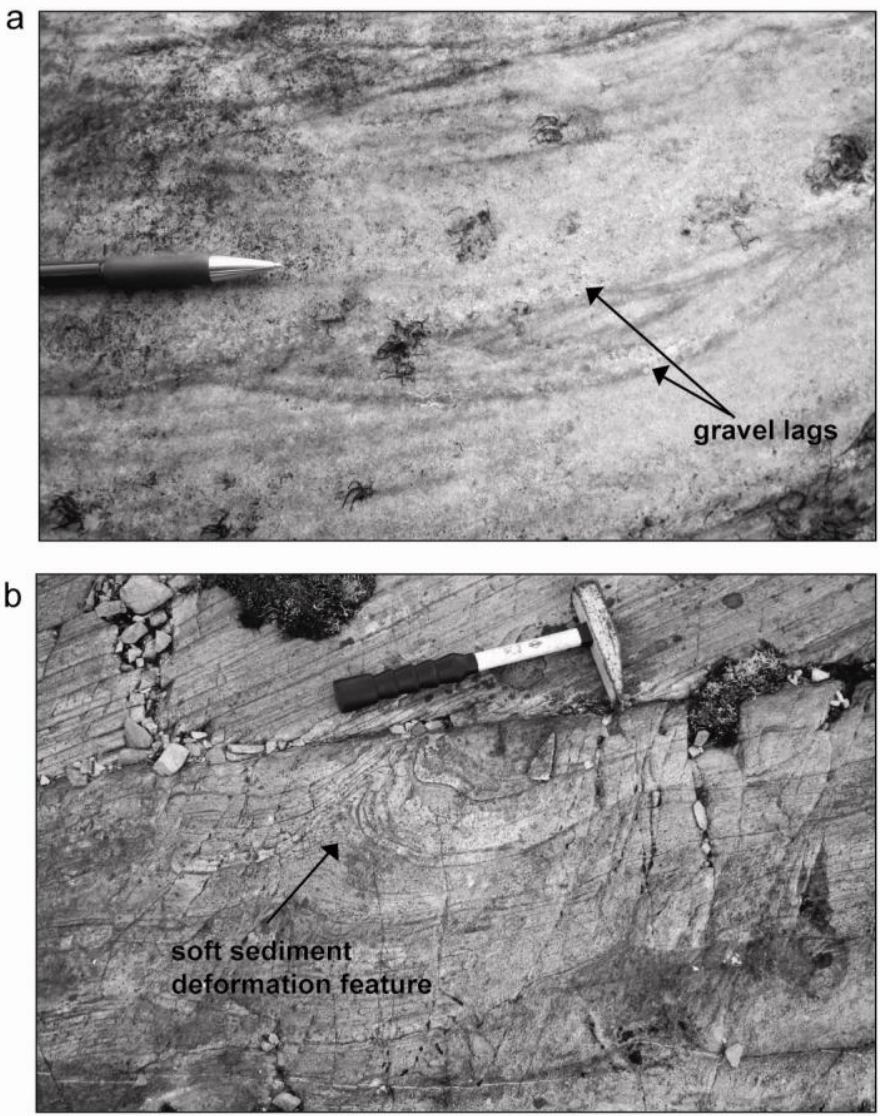
Fig. 10. Sedimentological log of LFC3 facies in the upper part of the Crom Psammite Formation, Glen Calvie (GR 246878, 885958). Grey triangles mark coarsening-upward units. Individual coarsening-upward cycles in the lithofacies are similar in both the lower and upper part of the Crom Psammite Formation.

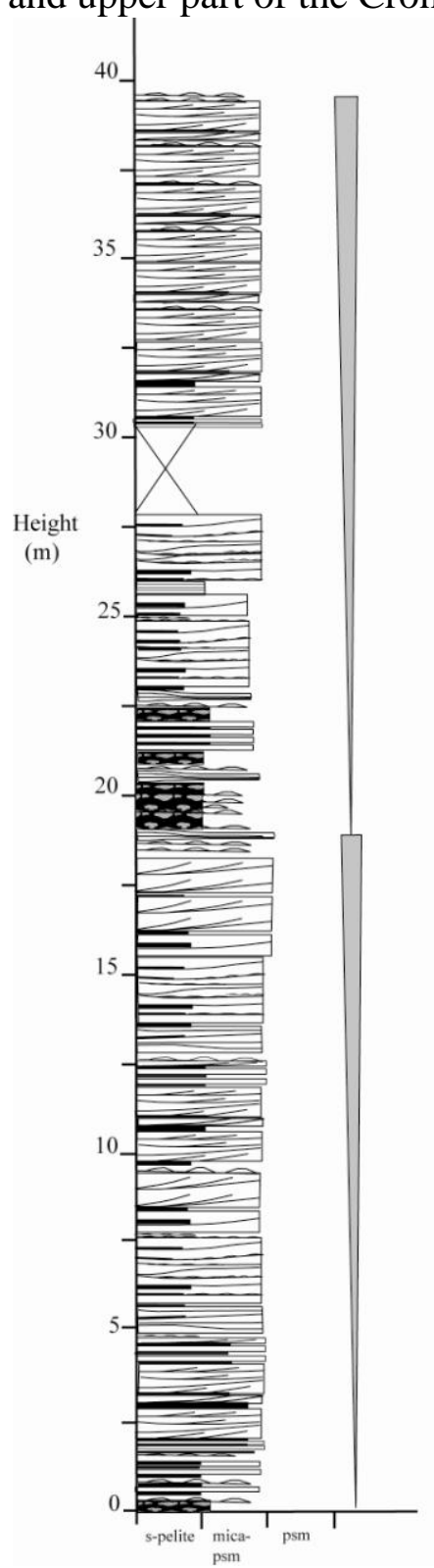


Fig. 11. Photographs of typical LFC2 facies in the upper Crom Psammite Formation: pelite and semi-pelite interbedded with thin cross-laminated tabular psammite (GR 234790, 888870).
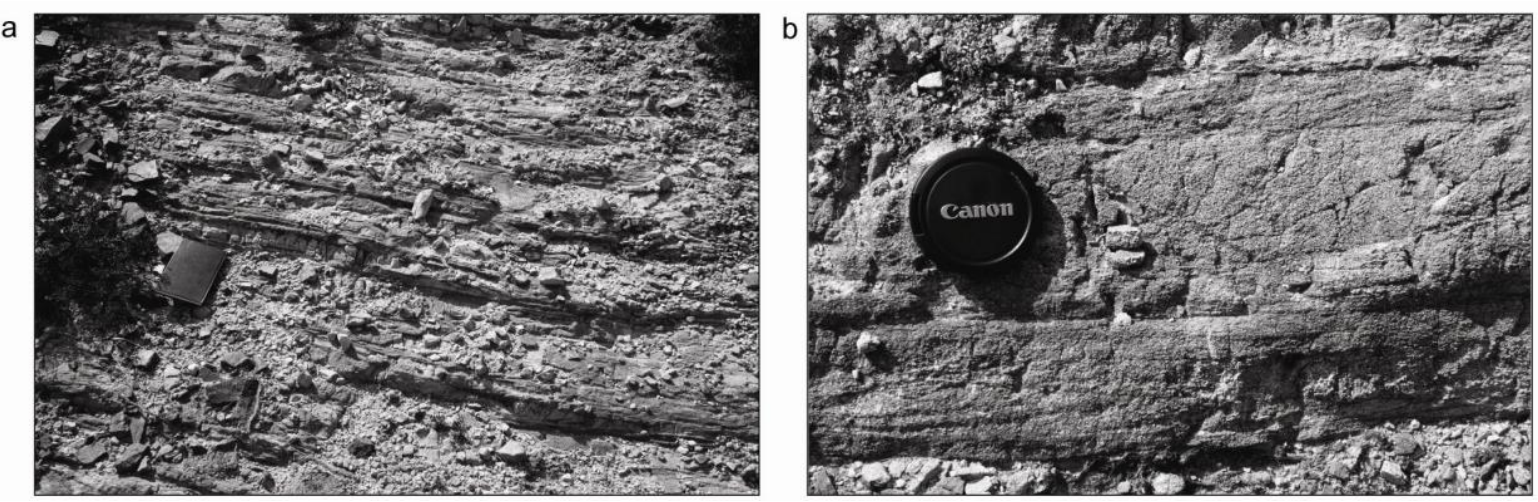
Fig. 12. Schematic stratigraphic section of the Morar Group, which integrates all the detailed sedimentological logs from work in the Morar Group, and shows the inferred palaeoenvironments, and possible correlations with the Torridon Group. Lines of sedimentological logs in the Morar Group from this study are marked by black bars; logs from previous work are marked by white bars. Arrows denote general direction of palaeoflow. The right hand column indicates inferred base-level trends in the basin, and demarcates points critical to basin evolution (e.g. flooding surfaces).

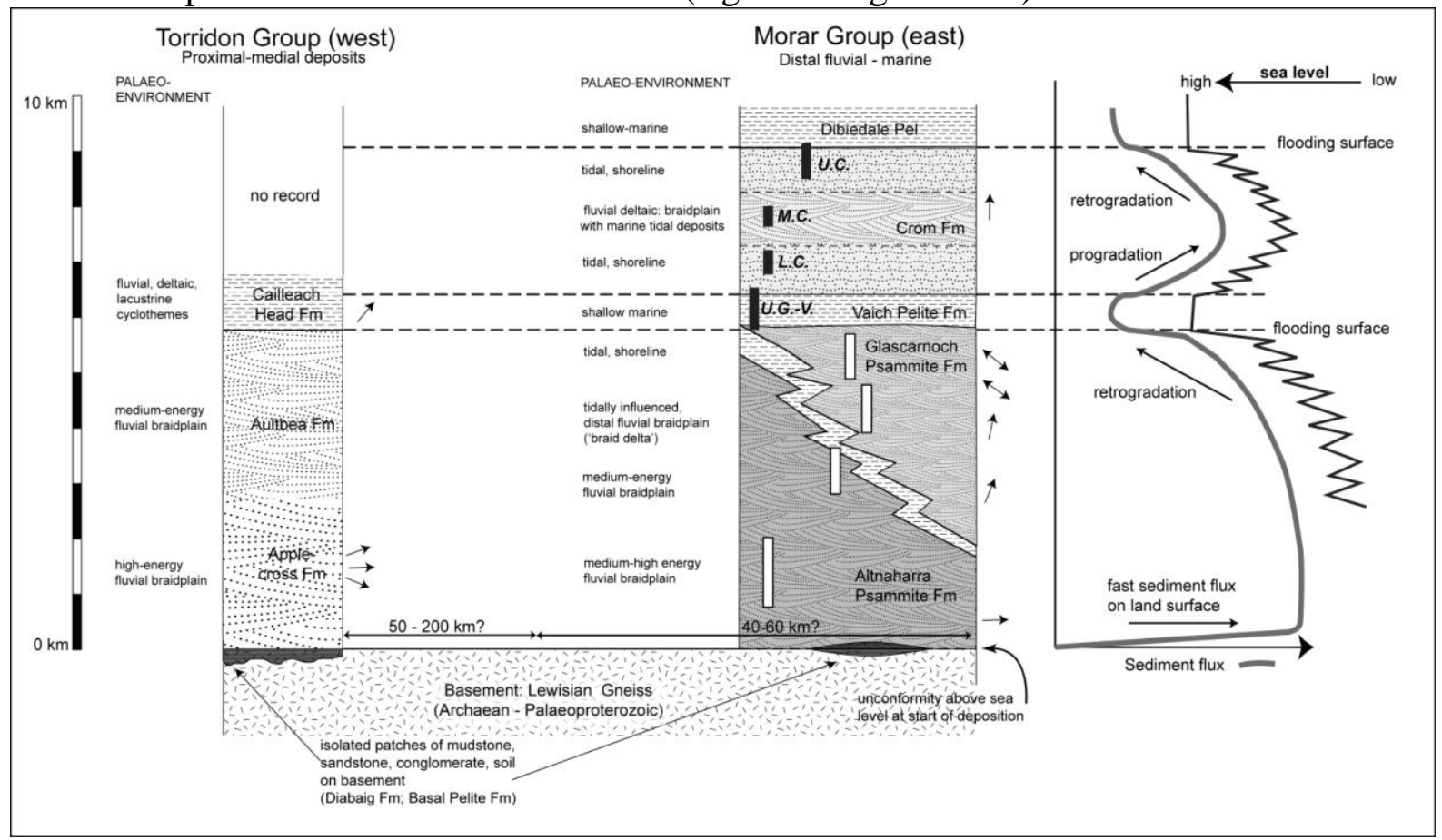

